\title{
Trisubstituted $(E)$-Alkene Dipeptide Isosteres as $\beta$-Turn Promoters in the Gramicidin S Cyclodecapeptide Scaffold
}

\author{
Jingbo Xiao§, Bernard Weisblum ${ }^{\#}$, and Peter Wipf ${ }^{\star}, \S$ \\ §Department of Chemistry and Center for Chemical Methodologies \& Library, Development, University of \\ Pittsburgh, Pittsburgh, Pennsylvania 15260 \\ \#Pharmacology Department, University of Wisconsin Medical School, 1300 University Avenue, Madison, \\ Wisconsin 53706
}

\section{Abstract}

A concise synthesis of a gramicidin $\mathrm{S}$ analogue with trisubstituted $(E)$-alkene dipeptide isostere (TEADI) replacements at both ${ }^{D}$ Phe-Pro positions was realized. Conformational analysis demonstrated that TEADIs can serve as type II $\beta$-turn promoters in a cyclic scaffold and successfully mimic a proline residue.

Peptides demonstrate a wide range of diverse physiological properties as hormones, enzyme inhibitors, growth promoters, signaling pathways modulators, antimicrobial agents, etc. ${ }^{1}$ In order to overcome the limited bioavailability of peptides, ${ }^{2}$ we are studying the synthesis and pharmacological evaluation of bioisosteric replacements of the amide bond. ${ }^{3}$ The relatively rigid trisubstituted $(E)$-alkene dipeptide isosteres $(\psi[(E)-\mathrm{C}(\mathrm{R})=\mathrm{CH}], \mathrm{R} \neq \mathrm{H}$, TEADIs) maintain $\omega$-angle planarity and represent useful structural surrogates of hydrolytically labile amide bonds. ${ }^{4}$ In addition, TEADIs were found to have potential as $\beta$-turn promoters in acyclic sequences in our previous studies. ${ }^{5}$ In a continuation of this work, we have now started to introduce these building blocks into biologically active cyclic peptide sequences as surrogates of the powerful turn-inducing ${ }^{D}$ Phe-Pro sequence ${ }^{6}$ and evaluate their potential as $\beta$-turn promoters as well modulators of biological and metabolic properties. ${ }^{7}$

Since its discovery in $1942,{ }^{8}$ the cyclodecapeptide antibiotic Gramicidin S (GS, cyclo[(ValOrn-Leu- ${ }^{D}$ Phe-Pro- $\left.)_{2}\right]$ ) has served as an inspiration for the design of antibacterial agents and antimicrobial peptides, as well as a model system for conformational mimicry. ${ }^{9}$ GS is therefore a particularly significant target for the evaluation of alkene peptide isosteres as surrogates for the type II' $\beta$-turn inducing sequence.

The ${ }^{D}$ Phe-Pro reverse turn is a critical feature of the rigid amphipathic antiparallel $\beta$-pleated sheet conformation of GS. ${ }^{10,11}$ In earlier work, ${ }^{7}$ we were able to replace the Leu- ${ }^{D}$ Phe peptide bond in GS with a $\psi\left[(E)-\mathrm{C}\left(\mathrm{CF}_{3}\right)=\mathrm{CH}\right]$ isostere with minimal perturbation of secondary structure and biological activity, while the corresponding $\psi\left[(E)-\mathrm{C}\left(\mathrm{CH}_{3}\right)=\mathrm{CH}\right]$ isostere failed to maintain the $\beta$-pleated sheet conformation according to $\mathrm{CD}$ and NMR analyses. A different situation presents itself when the ${ }^{D}$ Phe-Pro peptide bond is replaced. Since the ${ }^{D}$ Phe carbonyl group is not involved in intramolecular $\mathrm{H}$-bonding or dipolar interactions, a $\psi\left[(E)-\mathrm{C}\left(\mathrm{CH}_{3}\right)\right.$ $=\mathrm{CH}]$ surrogate should be as effective as a trifluoromethylated congener in conformationally preorganizing the chain. The restricted backbone rotation imposed by the $\mathrm{A}^{1,3}$-strain across the trisubstituted alkene, and, to a lesser extent, the $\mathrm{A}^{1,2}$-strain experienced by substituents 
attached to the alkene, should be sufficient for both methyl and trifluoromethyl groups to impose the reverse turn. Furthermore, neither alkene isostere provides an $\mathrm{NH}$ hydrogen bond donor group that can lead to the stabilization of $\gamma$-turns or other competitive backbone folding patterns that would interfere with the desired $\beta$-turn motif. These properties lead, theoretically, to a close match of isostere and ${ }^{D}$ Phe-Pro features (Figure 1) ${ }^{5 \mathrm{~b}}$ We now report an experimental confirmation of this hypothesis.

Due to the lability of phenylacetaldimines, the sulfinyl adduct $3^{12}$ was employed in the organometallic allylation reaction (Scheme 1). ${ }^{13}$ Using our hydrozirconation/Zr $\Rightarrow \mathrm{Zn}$ transmetalation methodology, ${ }^{14,15}$ the alkenylzinc species derived from the chiral internal alkyne $2^{13 b}$ was added to 3 , affording the allylic amide $\mathbf{4}$ in $64 \%$ yield as a $\sim 1: 1$ mixture of diastereomers. Deprotection of the TBDPS group with TBAF provided the primary alcohol 5. The two diastereomers could not be separated after conversion of $\mathbf{5}$ to the corresponding acetates; $3 \mathrm{f}, 7$ however, a two-step oxidation with Dess-Martin periodinane, 16,17 followed by coupling with valine methyl ester provided pseudo-tripeptides $\mathbf{6}$ and $\mathbf{7}$ which were separated by preparative $\mathrm{C}_{18}$ RP HPLC. ${ }^{18}$

Saponification of pseudo-tripeptide $\mathbf{7}$ followed by fragment coupling with dipeptide H-Orn $(\mathrm{Cbz})-\mathrm{Leu}-\mathrm{OMe}$ in the presence of EDC as a coupling reagent afforded the pseudopentapeptide 8 in $96 \%$ yield over two steps. We initially envisioned a one-pot dimerizationcyclization of $\mathbf{8}$; however, this approach resulted exclusively in the formation of cyclized pseudo-pentapeptide. In contrast, the stepwise coupling proceeded smoothly to give the pseudo-decapeptide $\mathbf{9}$ in excellent yield. Saponification of $\mathbf{9}$ and stepwise removal of the Boc protecting group followed by macrolactamization afforded the desired bis-Cbz-protected GS analogue $\mathbf{1 0}$ in $50 \%$ yield after preparative $\mathrm{C}_{18}$ RP HPLC purification (Scheme 2).

The chemical shifts of all amide protons in $\mathbf{1 0}$ were assigned using a combination of COSY, NOESY, HMQC and HMBC data sets collected in DMSO- $d_{6}$ at $338 \mathrm{~K}$, since some amide ${ }^{1} \mathrm{H}$ NMR signals were obscured at $298 \mathrm{~K}$. Variable temperature NMR was applied to probe the conformation of $\mathbf{1 0}$ in solution and determine the level of intramolecular hydrogen bonding (Table 1). Temperature shift coefficients for $\mathbf{1 0}$ were in close agreement with the values for bis-Cbz-protected GS $\left(\mathbf{C b z}_{2} \mathbf{G S}\right){ }^{7}$ The NH shifts of Leu and Val residues in $\mathbf{1 0}$ showed small temperature coefficients of -1.9 and $-1.8 \mathrm{ppb} / \mathrm{K}$, respectively, whereas Orn- $\mathrm{NH}$ and ${ }^{D} \mathrm{Phe}-\mathrm{NH}$ were solvent exposed, thus indicating a hydrogen bonding array typical for an antiparallel $\beta$ pleated sheet conformation. ${ }^{19}$ Furthermore, NOESY spectra showed transannular Leu-NHVal-NH and Val-NH_$-{ }^{D}$ Phe-Hacontacts for $\mathbf{1 0}$ in agreement to what was found for $\mathbf{C b z}_{\mathbf{2}} \mathbf{G S}$ (Figure 2). The resulting ten-membered intramolecular $\mathrm{H}$-bonding interaction between the valine amide $\mathrm{NH}$ and the carbonyl group of the leucine residue is typical for a type II' $\beta$-turn. 20

Further confirmation of the close match between the secondary structures of $\mathbf{1 0}$ and $\mathbf{C b z}_{\mathbf{2}} \mathbf{G S}$ was provided by circular dichroism (CD) spectra in EtOH (Figure 3). The strong negative band at $205-225 \mathrm{~nm}$ and a shoulder in the region of $225-235 \mathrm{~nm}$ for both $\mathbf{1 0}$ and $\mathbf{C b z}_{\mathbf{2}} \mathbf{G S}$ is consistent with a combination of a type II' $\beta$-turn and a $\beta$-sheet conformation in these compounds. ${ }^{21}$ This result, along with the data from NOESY and variable temperature NMR experiments, further confirmed that the methyl $(E)$-alkene dipeptide isostere replacements at the former ${ }^{D}$ Phe-Pro positions strongly promoted the archetypical architecture of the parent peptide, gramicidin S. An MMFF-minimized structure for $\mathbf{1}$ that is in agreement with all experimental data is shown in Figure $4 .^{22}$

Our previous biological studies showed that free amine functions on the ornithine side chains were necessary to retain the antibacterial, antifungal, and hemolytic activities of GS. ${ }^{7} \mathrm{The} \mathrm{Cbz}$ protecting groups in $\mathbf{1 0}$ were successfully removed by hydrogenolysis in the presence of $10 \%$ 
$\mathrm{Pd} / \mathrm{C}$ in a $0.02 \mathrm{M} \mathrm{HCl} / \mathrm{MeOH}$ solution, without concomitant reduction of the trisubstituted (E)-alkene moieties (Scheme 3). As expected, the hydrochloride salt of 1 also exhibited functional mimicry of the natural product, with an MIC of $\sim 20 \mu \mathrm{g} / \mathrm{mL}$ against Bacillus subtilis, and thus equipotent with GS hydrochloride (MIC $\sim 15 \mu \mathrm{g} / \mathrm{mL}$ in the same assay).

The development of proline mimics is of considerable current interest, due to the helix-breaking and unique conformational properties of this amino acid residue. ${ }^{23}$ We have now demonstrated that a trisubstituted $(E)$-alkene dipeptide isostere can serve as a bioisosteric replacement for the ${ }^{D}$ Phe-Pro type II' $\beta$-turn in the cyclopeptide antibiotic gramicidin S. The solution conformational analysis and the biological assay of analogues $\mathbf{1 0}$ and $\mathbf{1}$, respectively, provides a strong validation of our design principles. Furthermore, the hydrozirconation/Zr $\Rightarrow \mathrm{Zn}$ transmetalation/imine addition methodology was key to a rapid synthetic access to the target compounds.

\section{Supplementary Material}

Refer to Web version on PubMed Central for supplementary material.

\section{Acknowledgment}

This work was supported by the NIH/NIGMS P50 program (GM067082). J.X. gratefully acknowledges an Andrew W. Mellon Predoctoral Fellowship for support and Dr. Corey R. J. Stephenson (ETHZ) for helpful discussions.

\section{References}

1. (a) Kazmierski WM, Kenakin TP, Gudmundssona KS. Chem. Biol. Drug Des 2006;67:13. [PubMed: 16492145] (b) Clark RJ, Fischer H, Dempster L, Daly NL, Rosengren KJ, Nevin ST, Meunier FA, Adams DJ, Craik DJ. Proc. Natl. Acad. Sci. U. S. A 2005;102:13767. [PubMed: 16162671] (c) Ladner RC, Sato AK, Gorzelany J, De Souza M. Drug Disc. Today 2004;9:525.

2. Conradi RA, Hilgers AR, Ho NFH, Burton PS. Pharm. Res 1992;9:435. [PubMed: 1614980]

3. (a) Wipf P, Fritch PC. J. Org. Chem 1994;59:4875.Henninger, T.; Wipf, P. Methods in Molecular Biology Peptidomimetics. Walker, JM.; Kazmierski, WM., editors. Vol 23. Totowa: Humana Press; 1999. p. 125-136. (c) Mu Y, Stephenson CRJ, Kendall C, Saini SPS, Toma D, Ren S, Cai H, Strom SC, Day BW, Wipf P, Xie W. Mol. Pharmacol 2005;68:403. [PubMed: 15872116] (d) Wipf P, Werner S, Woo GHC, Stephenson CRJ, Walczak MAA, Coleman CM, Twining LA. Tetrahedron 2005;61:11488. (e) Levinson N, Hinman R, Patil A, Stephenson CRJ, Werner S, Woo GHC, Xiao J, Wipf P, Lynch KW. RNA 2006;12:925. [PubMed: 16556940] (f) Wipf P, Xiao J, Jiang J, Belikova NA, Tyurin VA, Fink MP, Kagan VE. J. Am. Chem. Soc 2005;127:12460. [PubMed: 16144372]

4. (a) Tamamura H, Koh Y, Ueda S, Sasaki Y, Yamasaki T, Aoki M, Maeda K, Watai Y, Arikuni H, Otaka A, Mitsuya H, Fujii N. J. Med. Chem 2003;46:1764. [PubMed: 12699395] (b) Yang H, Sheng XC, Harrington EM, Ackermann K, Garcia AM, Lewis MD. J. Org. Chem 1999;64:242. [PubMed: 11674109] (c) Oishi S, Miyamoto K, Niida A, Yamamoto M, Ajito K, Tamamura H, Otaka A, Kuroda Y, Asai A, Fujii N. Tetrahedron 2006;62:1416.

5. (a) Wipf P, Henninger TC, Geib SJ. J. Org. Chem 1998;63:6088. [PubMed: 11672228] (b) Wipf P, Henninger TC. J. Org. Chem 1997;62:1586.

6. Wadhwani P, Afonin S, Ieronimo M, Buerck J, Ulrich AS. J. Org. Chem 2006;71:55. [PubMed: 16388617]

7. Xiao J, Weisblum B, Wipf P. J. Am. Chem. Soc 2005;127:5742. [PubMed: 15839644]

8. Gauze GF, Brazhnikova MG. Am. Rev. Soviet Med 1944;2:134.

9. See:GrotenbregGMBuizertAEMLlamas-SaizALSpalburgEVan HooftPAVDe NeelingAJNoortDVan RaaijMJVan Der MarelGAOverkleeftHSOverhandMJ. Am. Chem. Soc20061287559and references cited therein [PubMed: 16756311] 
10. (a) Yamada K, Unno M, Kobayashi K, Oku H, Yamamura H, Araki S, Matsumoto H, Katakai R, Kawai M. J. Am. Chem. Soc 2002;124:12684. [PubMed: 12392415] (b) Doi M, Fujita S, Katsuya Y, Sasaki M, Taniguchi T, Hasegawa H. Arch. Biochem. Biophys 2001;395:85. [PubMed: 11673869]

11. (a) Kondejewski LH, Farmer SW, Wishart DS, Hancock REW, Hodges RS. Int. J. Pept. Protein Res 1996;47:460. [PubMed: 8836773] (b) Kondejewski LH, Farmer SW, Wishart D, Kay CM, Hancock REW, Hodges RS. J. Biol. Chem 1996;271:25261. [PubMed: 8810288]

12. Côté A, Boezio AA, Charette AB. Proc. Nat. Acad. Sci. U. S. A 2004;101:5405.

13. (a) Wipf P, Xiao J, Geib SJ. Adv. Synth. Catal 2005;347:1605. (b) Wipf P, Xiao J. Org. Lett 2005;7:103. [PubMed: 15624988]

14. (a) Wipf P, Jahn H. Tetrahedron 1996;52:12853. (b) Wipf P, Kendall C. Top. Organomet. Chem 2004;8:1.

15. (a) Wipf P, Kendall C, Stephenson CRJ. J. Am. Chem. Soc 2001;123:5122. [PubMed: 11457353] (b) Wipf P, Kendall C, Stephenson CRJ. J. Am. Chem. Soc 2003;125:761. [PubMed: 12526676]

16. Dess DB, Martin JC. J. Org. Chem 1983;48:4155.

17. Wipf P, Kim Y, Goldstein DM. J. Am. Chem. Soc 1995;117:11106.

18. The structural assignment of $\mathbf{6}$ and $\mathbf{7}$ was based on the ozonolysis product $\mathbf{1 2}$, which was identical to the methylation product obtained from Boc- ${ }^{D}$ Phe-OH (11) by HPLC co-injection (Pace RD, Kabalka GW. J. Org. Chem 1995;60:4838.).

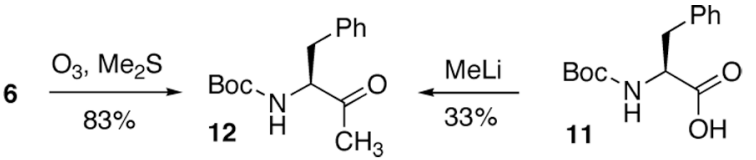

19. (a) Wipf P, Fritch PC, Geib SJ, Sefler AM. J. Am. Chem. Soc 1998;120:4105. (b) Imperiali B, Fisher SL, Moats RA, Prins TJ. J. Am. Chem. Soc 1992;114:3182. (c) Kessler H. Angew. Chem. Int. Ed 1982;21:512.

20. Ball JB, Hughes RA, Alewood PF, Andrews PR. Tetrahedron 1993;49:3467.

21. (a) Tamaki M, Akabori S, Muramatsu I. Bull. Chem. Soc. Jpn 1993;66:3113.Woody, RW. Chapter 17. In: Nakanishi, K.; Berova, N.; Woody, RW., editors. Circular Dichroism. New York: VCH; 1994. p. 473-496.

22. A 4300-step conformational equilibrium search was performed with Spartan 04. Irvine, CA: Wavefunction, Inc;

23. (a) Jenkins CL, Vasbinder MM, Miller SJ, Raines RT. Org. Lett 2005;7:2619. [PubMed: 15957905] (b) Cordero FM, Pisaneschi F, Batista KM, Valenza S, Machetti F, Brandi A. J. Org. Chem 2005;70:856. [PubMed: 15675843] (c) Wang XJ, Hart SA, Xu B, Mason MD, Goodell JR, Etzkorn FA. J. Org. Chem 2003;68:2343. [PubMed: 12636401] (d) Halab L, Lubell WD. J. Am. Chem. Soc 2002;124:2474. [PubMed: 11890796] (e) Otaka A, Katagiri F, Kinoshita T, Odagaki Y, Oishi S, Tamamura H, Hamanaka N, Fujii N. J. Org. Chem 2002;67:6152. [PubMed: 12182656] 

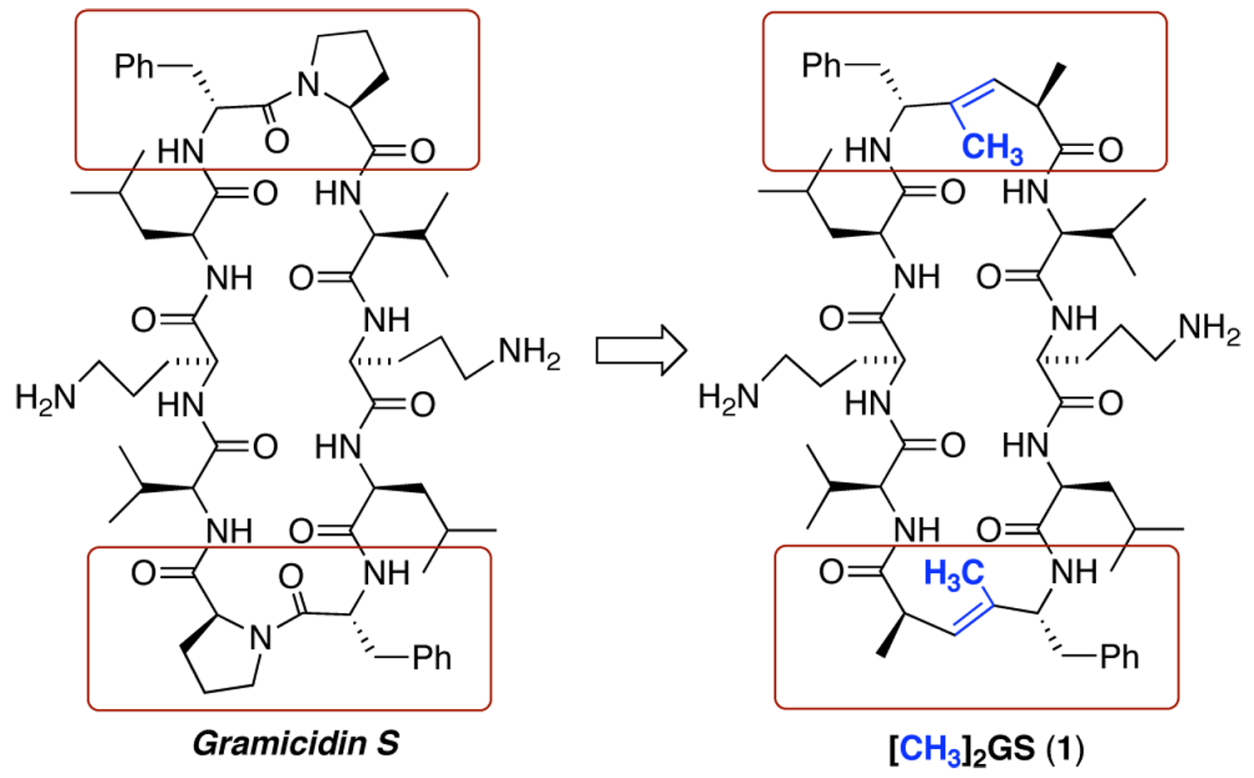

Figure 1.

GS and analogue with $\psi\left[(E)-\mathrm{C}\left(\mathrm{CH}_{3}\right)=\mathrm{CH}\right]$ peptide bond surrogates. 

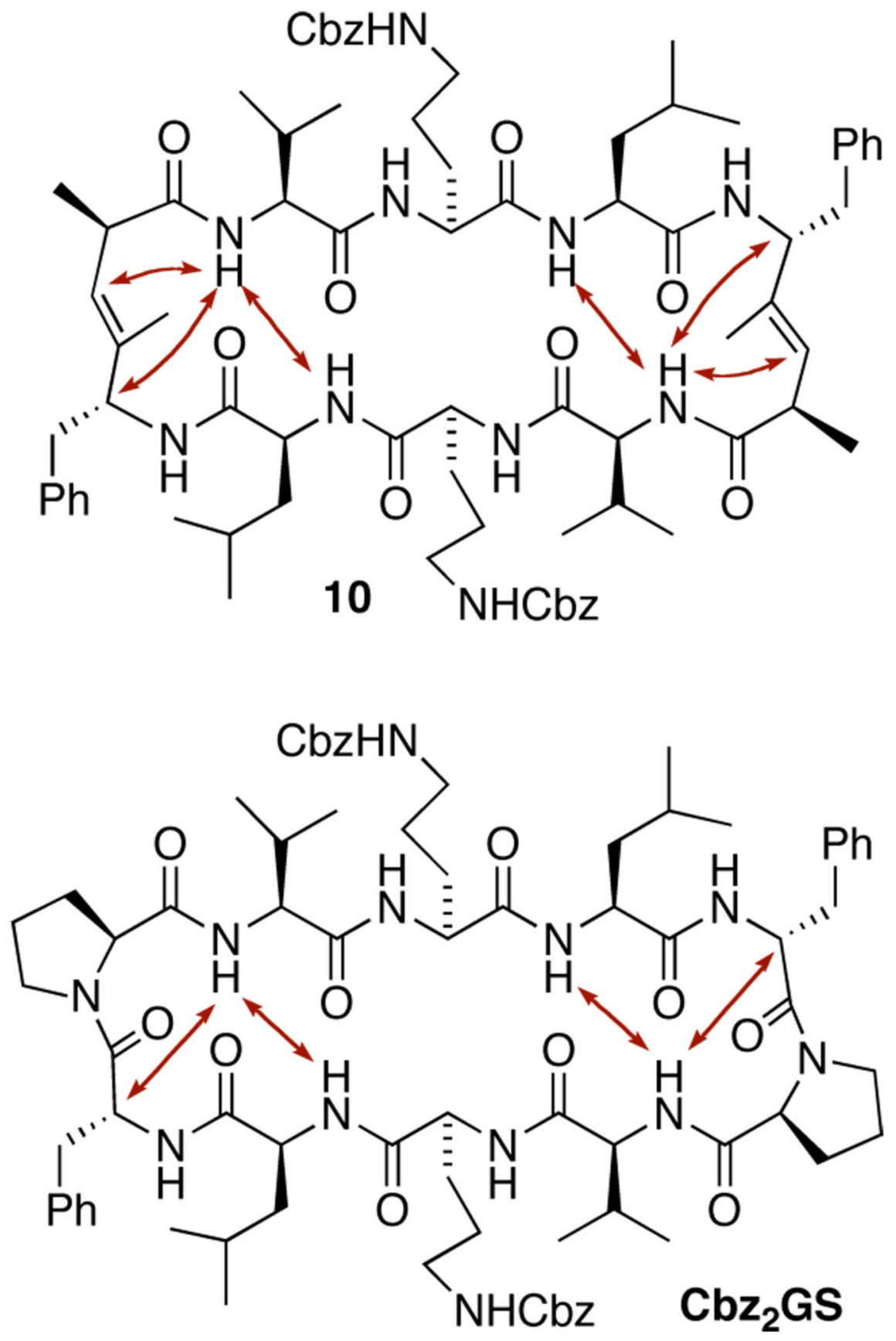

Figure 2.

Observed NOEs for $\mathbf{1 0}$ and $\mathbf{C b z}_{\mathbf{2}} \mathbf{G S}$. 


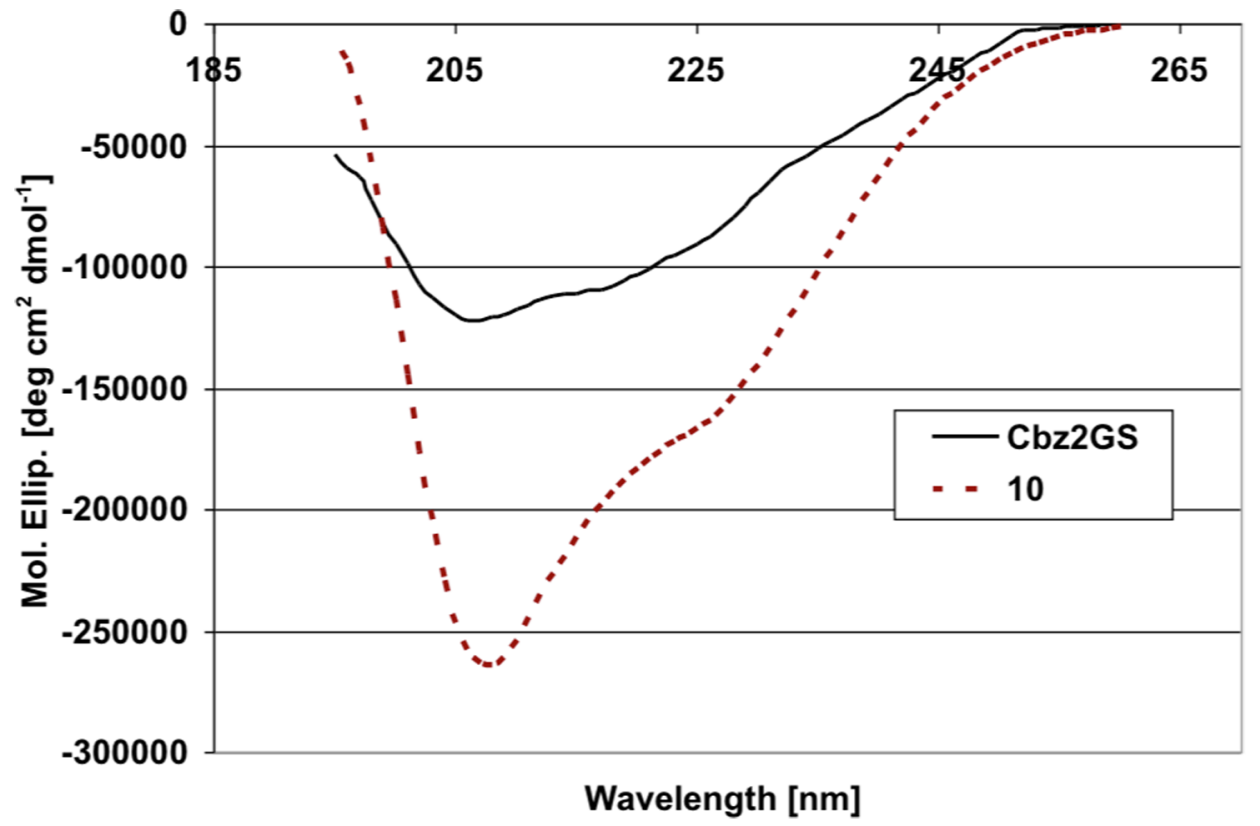

Figure 3.

CD Spectra of $\mathbf{1 0}$ and $\mathbf{C b z}_{2} \mathbf{G S}$ in $\mathrm{EtOH}$. 

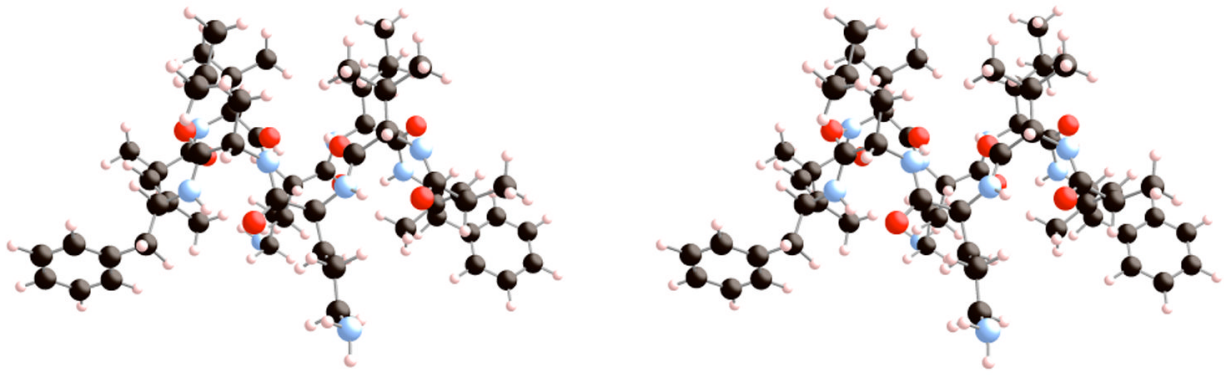

Figure 4.

Stereoview of the minimized structure of $\mathbf{1}$ derived from an MMFF conformational search algorithm. 


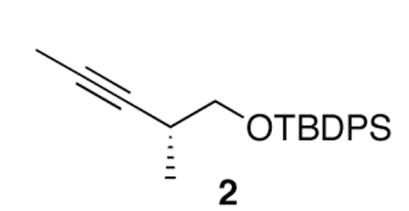

1. $\mathrm{Cp}_{2} \mathrm{ZrHCl}$

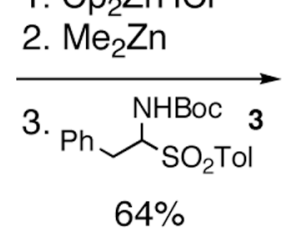<smiles>O=C(O)[PbH]</smiles><smiles>CNC(Cc1ccccc1)/C(C)=C/[C@H](C)CO[PbH2]</smiles><smiles>CC(=O)OC(=O)NC(Cc1ccccc1)/C(C)=C/[C@H](C)CO</smiles><smiles>[3H]C(=O)OC(=O)N[C@H](Cc1ccccc1)/C(C)=C/[C@H](C)C(=O)N[C@H](C(=O)OC)C(C)C</smiles>

Scheme 1.

Synthesis of Boc- ${ }^{D}$ Phe- $\psi\left[(E)-C\left(\mathrm{CH}_{3}\right)=\mathrm{CH}\right]-$ Pro-Val-OMe 


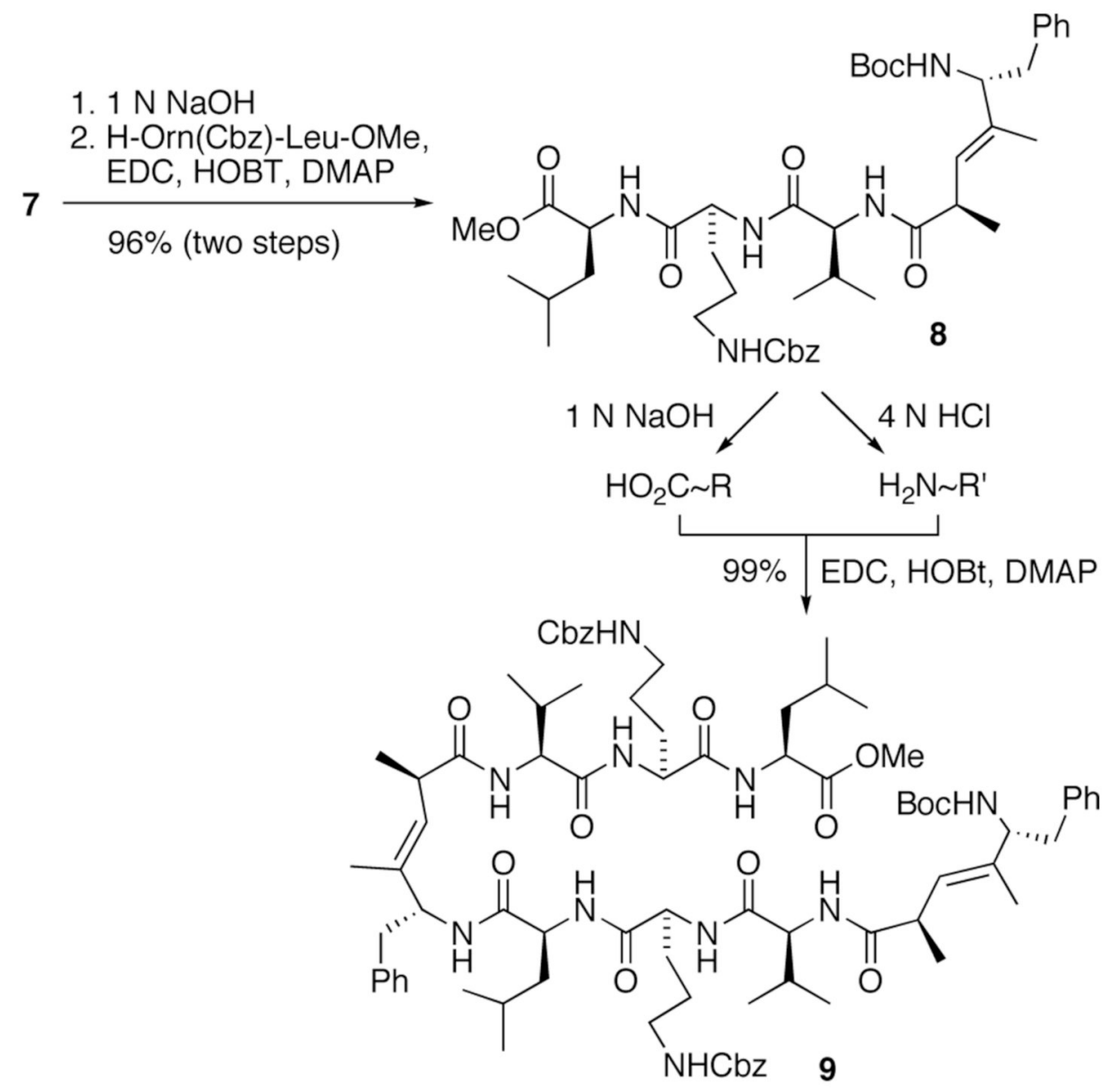

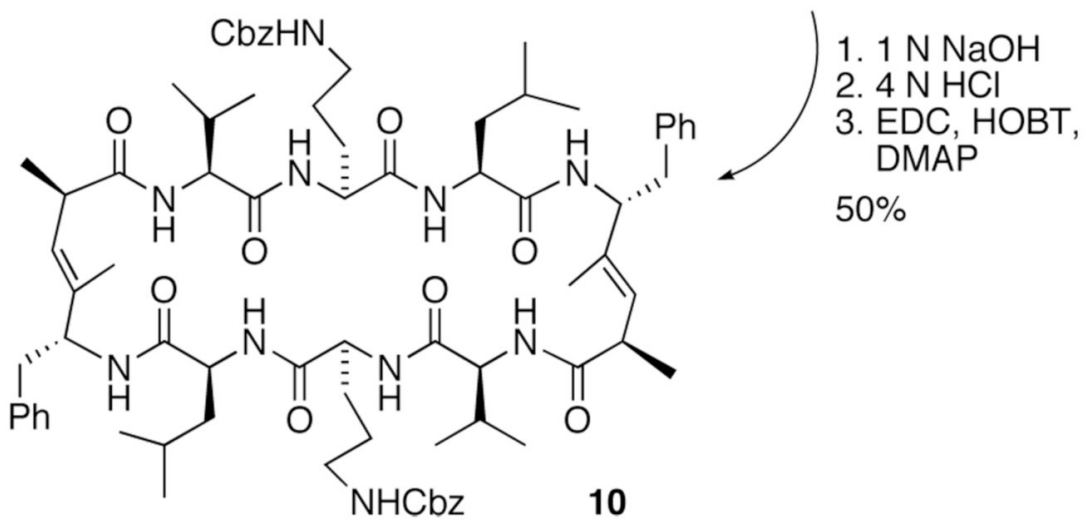

Scheme 2.

Fragment condensation and synthesis of pseudo-cyclodecapeptide $\mathbf{1 0}$ 


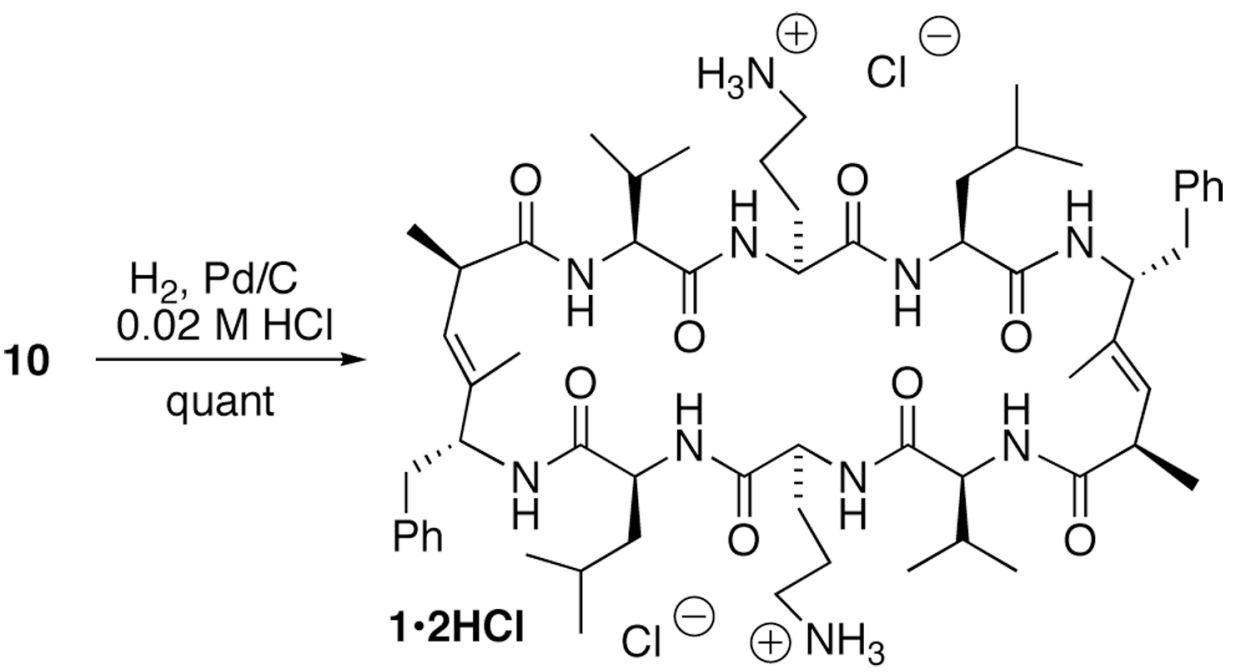

Scheme 3.

Synthesis of the hydrochloride salt of $\left[\mathrm{CH}_{3}\right]_{2} \mathrm{GS}(\mathbf{1} \cdot \mathbf{2 H C l})$ 


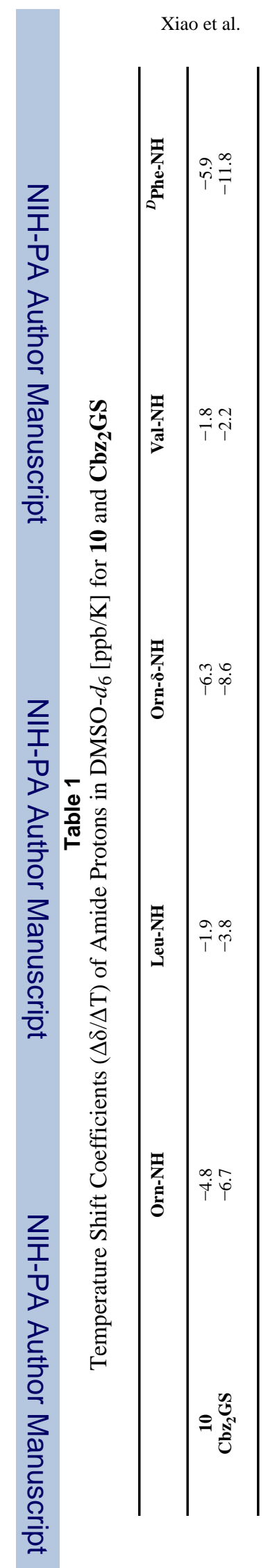

Page 12 